\title{
Evaluation of Groundwater Quality and Its Suitability for Domestic and Irrigation Use in Parts of the Chandauli-Varanasi Region, Uttar Pradesh, India
}

\author{
Shubhra Singh1, N. Janardhana Raju ${ }^{{ }^{*}}$, Ch. Ramakrishna ${ }^{2}$ \\ ${ }^{1}$ School of Environmental Sciences, Jawaharlal Nehru University, New Delhi, India \\ ${ }^{2}$ Department of Environmental Studies, GITAM University, Visakhapatnam, India \\ Email: ${ }^{*}$ rajunj7@gmail.com
}

Received 2 April 2015; accepted 19 May 2015; published 22 May 2015

Copyright (C) 2015 by authors and Scientific Research Publishing Inc. This work is licensed under the Creative Commons Attribution International License (CC BY). http://creativecommons.org/licenses/by/4.0/

\section{Abstract}

The present study focused on the hydrochemistry of groundwater in parts of Chandauli-Varanasi region to assess the quality of groundwater for determining its suitability for drinking and agricultural purposes. Urbanization and agriculture activities have a lot of impacts on the groundwater quality of the study area. A total of $\mathbf{7 0}$ ground water samples were collected randomly from different sources viz. hand pump, dug wells and bore wells, and analyzed for major cations and anions. The domination of cations and anions was in the order of $\mathrm{Na}>\mathrm{Ca}>\mathrm{Mg}>\mathrm{K}$ and $\mathrm{HCO}_{3}>\mathrm{Cl}>$ $\mathrm{SO}_{4}>\mathrm{NO}_{3}>\mathrm{F}$. The Piper classification for hydrogeochemical facies indicates that alkaline earth exceeds alkalis and weak acids exceed strong acid. Water quality index rating was calculated to quantify overall water quality for human consumption. Out of $\mathbf{7 0}$ groundwater samples, $\mathbf{7 \%}$ and $10 \%$ samples exhibit water unsuitable for drinking purposes in pre- and post-monsoon, respectively, due to effective leaching of ions, direct discharge of domestic effluents and agricultural activities. Residual sodium carbonate values revealed that $6 \%$ sample is not suitable for irrigation purposes in both the seasons due to low permeability of the soil. The calculated values of PI indicate that the water for irrigation uses is excellent to good quality in both seasons. As per Wilcox's diagram and US salinity laboratory classification, most of the groundwater samples are suitable for irrigation except one sample which is unsuitable for irrigation purposes. The overall quality of groundwater in post-monsoon season in all chemical constituents is on the higher side due to dissolution of surface pollutants during the infiltration and percolation of rainwater at few places due to agricultural and domestic activities.

${ }^{*}$ Corresponding author. 


\section{Keywords}

\section{Groundwater Quality, Hydrogeochemical Facies, Drinking Water, Irrigation Water}

\section{Introduction}

Groundwater is a valuable natural resource; it occurs almost in all geological formations under the earth surface not in a single widespread aquifer but in thousands of local aquifer systems with similar characteristics. In tropical regions, groundwater plays an important role with context to fluctuating and increasing contamination of groundwater. The groundwater is used in study area for both domestic and agricultural purposes. Agriculture is the main source of livelihood of the population and ground water is the major source of irrigation. Groundwater gets contaminated with a variety of pollutants generated from diverse sources such as agriculture, industrial and domestic. The availability of this important natural resource has been taken for granted increasing ground water use and pollution generation has crossed the sustainable limits in many parts, due to fast changing land use pattern. There has been tremendous increase in demand for fresh water due to population growth and intense agriculture activities. With rapid increase in population and growth of industrialization, groundwater quality is being increasingly threatened by disposal of urban and industrial solid waste [1]. Open dumping is the most common way to dispose municipal and industrial wastes. Subsequent leaching of toxic contaminants through the dumping site also leads to extensive contamination of ground water at many places. It has been estimated that once pollution enters the subsurface environment, it may remain concealed for many years; rendering groundwater is unsuitable for consumption and other uses [2]. Rate of depletion of groundwater levels and deterioration of groundwater quality is of immediate concern in major cities and towns of the country. Variation of groundwater quality in an area is a function of physicochemical parameters that are greatly influenced by geological formations and anthropogenic activities.

The source of about $90 \%$ of drinking and irrigation water is from groundwater resources in study area. However, this water resource is facing problems including quality hazard in many areas where the exposure to pollution from agriculture and urbanization in shallow groundwater aquifers makes the water unfit for human consumption. Land use for urbanization and agricultural purpose in the Varanasi city has increased at an alarming rate during the last few decades. Borehole sediments revealed that multistoried sand bodies generated as a result of channel migration provide excellent aquifers confined by a thick zone of muddy sediments near the surface in Varanasi City [3]. In complex multilayered alluvial formations, the shallowest phreatic aquifer is often the most vulnerable to anthropogenic pollution and the most susceptible to saline intrusion. The aim of the study was to investigate the quality of ground water and to discuss the hydrochemical facies, water quality index and classify the groundwater for domestic and irrigation uses in the Chandauli-Varanasi, UP.

\section{Study Area and Hydrogeology}

The study area covers about $302 \mathrm{Km}^{2}$ and falls in Survey of India toposheets $63 \mathrm{O} / 3,63 \mathrm{O} / 4,63 \mathrm{~K} / 15$ and 63 $\mathrm{K} / 16$. Geographically this area lies between the latitude $25^{\circ} 20^{\prime} \mathrm{N}-25^{\circ} 12.7^{\prime} \mathrm{N}$ and longitude $82^{\circ} 58^{\prime} \mathrm{E}-83^{\circ} 10^{\prime} \mathrm{E}$ (Figure 1) is located in the middle Ganga plain of Indian sub-continent. The study area belongs to the middle Ganga plain with an average height of about $76.19 \mathrm{~m}$ above the mean sea level with even topography. The Ganga is the principal river flowing incised into its narrow valley from south to north direction. The study area falls in the subtropical climate region. The area experiences three distinct seasons namely summer, rainy and winter. The maximum temperature is recorded to be $48^{\circ} \mathrm{C}$ and $24^{\circ} \mathrm{C}$ and minimum $32^{\circ} \mathrm{C}$ and $8{ }^{\circ} \mathrm{C}$ in summer and winter seasons, respectively. The study area receives greater of annual rainfall through south-west monsoon between June and September. The average annual rainfall of the study area is around $1020 \mathrm{~mm}$.

The unconsolidated near surface Pleistocene to recent fluvial sediments underlying most of the Ganga plains are generally potential aquifers. The alternating sand and clay layers have created a multitier aquifer system in the study area [3]. In the near surface Holocene sandy aquifer, groundwater occurs under water table conditions while deeper aquifers occur in semi-confined to confined conditions and are mainly used for irrigation and domestic purpose in the study area. Both dug wells and hand tube wells are used for groundwater extraction for different purposes. The shallow tube wells puncturing unconfined aquifers at an about 20 to $60 \mathrm{~m}$ depth have 


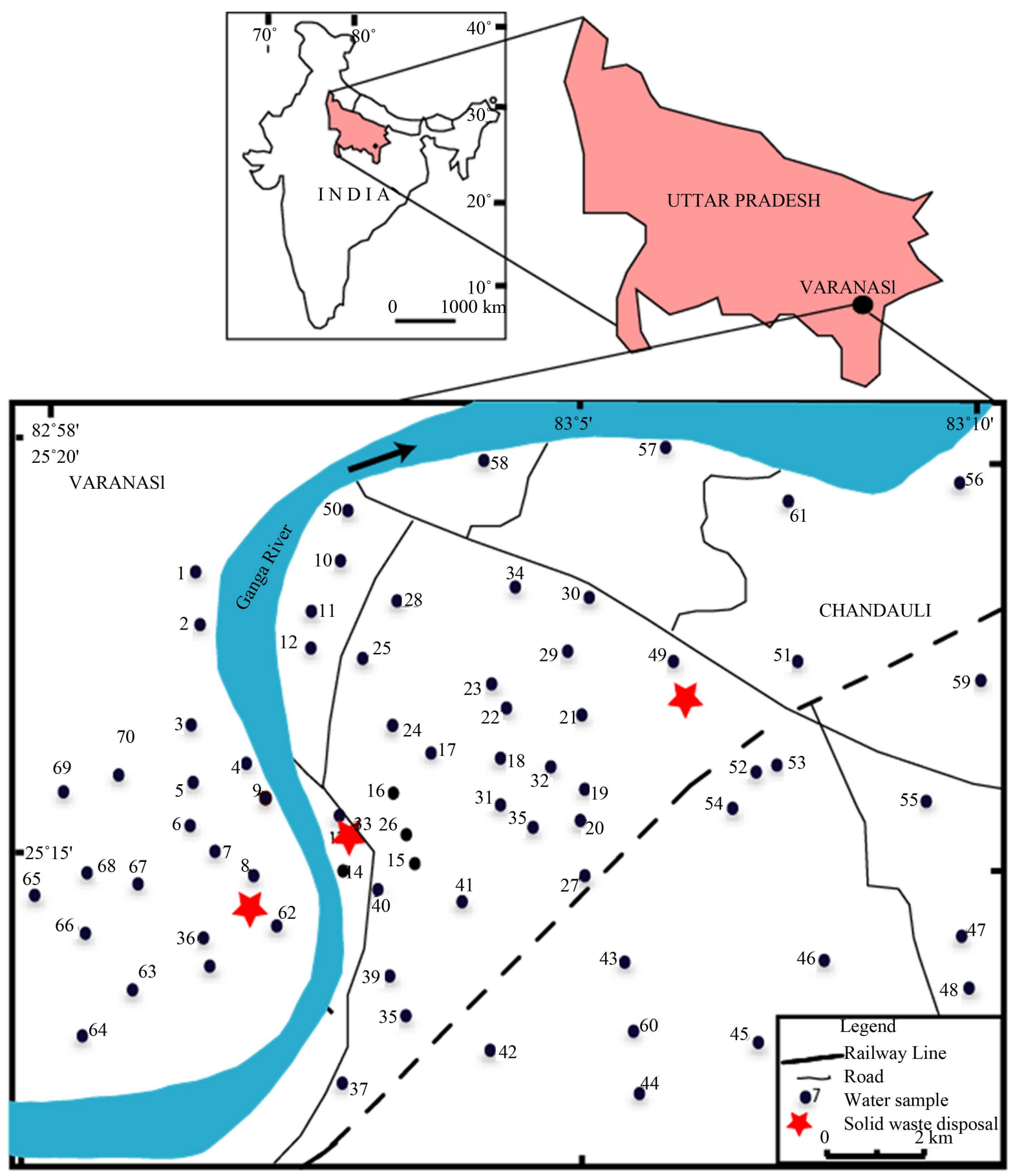

Figure 1. Physiographic and location map of study area.

water level fluctuation of 9 to $12 \mathrm{~m}$. The general depth of deep tube wells ranges from 60 to $250 \mathrm{~m}$ below ground level. The intensive pumping of groundwater due to population increase and urbanization affect [4] led to the fall of groundwater levels about $1.43 \mathrm{~m}$ in the Varanasi area [5].

\section{Methodology}

Dugwells and borewells were selected for sampling, which are functional and continuously in use for drinking and domestic purposes. A total of 70 groundwater samples were collected from dug wells and bore wells (hand 
pumps) in the study area during November, 2011 (Post-monsoon) and April, 2012 (Pre-monsoon). Sample bottles were cleaned by rinsing them with distilled water followed by their treatment with $1 \mathrm{M}$ solution of the preservative acid. In the case of bore wells (hand pumps) the water samples were collected after pumping for 10 15 minutes in order to remove stagnant groundwater. Physico-chemical parameters such as $\mathrm{pH}$, total dissolved solid (TDS) and electrical conductivity (EC) were measured by EC and $\mathrm{pH}$ meters in the field using the standard procedures. $\mathrm{F}$ was analyzed using Orion ion selective electrode 4 Star. Na and $\mathrm{K}$ were determined by using flame photometer (Elico CL-378). Ca, $\mathrm{HCO}_{3}$, hardness, alkalinity and $\mathrm{Cl}$ were analyzed by titrimetric method and magnesium estimated by the difference in the hardness and calcium [6]. $\mathrm{SO}_{4}, \mathrm{PO}_{4}, \mathrm{NO}_{3}$ and dissolved silica $\left(\mathrm{SiO}_{2}\right)$ were determined by UV-3200 double beam spectrophotometer model. The chemical data of groundwater samples are subjected to compute the ionic-balance-error between the total concentration of cations (Ca, $\mathrm{Mg}, \mathrm{Na}$ and $\mathrm{K}$ ) and total concentration of anions $\left(\mathrm{HCO}_{3}, \mathrm{Cl}, \mathrm{SO}_{4}, \mathrm{NO}_{3}\right.$ and $\mathrm{F}$ ) for testing accuracy of chemical analysis of each groundwater samples, before the interpretation of the chemical data is undertaken. The value of the ionic-balance-error is observed to be within the acceptable limit of $\pm 5 \%$ [7].

$$
\text { Electro neutrality }(\%)=[\text { total cations }+ \text { total anions/total cations }- \text { total anions }] * 100
$$

\section{Result and Discussion}

Understanding the quality of groundwater is important because it is the main factor which decides its suitability for domestic, agricultural and industrial purposes. Range of chemical parameters in groundwater and their comparison with WHO standards are presented in Table 1.

\subsection{Groundwater Classification and Hydrogeochemical Facies}

As water flows through an aquifer it assumes a characteristic chemical composition as a result of interaction

Table 1. Ranges of chemical parameters and their comparison with WHO standards for drinking water.

\begin{tabular}{|c|c|c|c|c|c|c|}
\hline \multirow{3}{*}{ Parameters } & \multicolumn{2}{|c|}{ Range } & \multirow{3}{*}{$\begin{array}{c}\text { Permissible } \\
\text { limits } \\
\text { WHO } \\
\text { (1997) }\end{array}$} & \multirow{2}{*}{\multicolumn{2}{|c|}{$\begin{array}{c}\text { Sample number } \\
\text { (\% of sample exceeding } \\
\text { permissible limit) }\end{array}$}} & \multirow{3}{*}{$\begin{array}{l}\text { Undesirable } \\
\text { effect }\end{array}$} \\
\hline & \multirow{2}{*}{ Pre } & \multirow{2}{*}{ Post } & & & & \\
\hline & & & & Pre-monsoon & Post-monsoon & \\
\hline $\mathrm{Ca}^{2+}$ & $30-260$ & $34-267$ & 200 & 29, $30(3 \%)$ & 29, 30, 58 (4\%) & Scale formation \\
\hline $\mathrm{Mg}^{2+}$ & $1.1-109$ & $1.9-110$ & 150 & & & - \\
\hline $\mathrm{Na}^{+}$ & $14-285$ & $25-298$ & 200 & $\begin{array}{c}13,16,20,24,69 \\
(7 \%)\end{array}$ & $\begin{array}{c}1,13,16,20 \\
24,27,69(10 \%)\end{array}$ & $\begin{array}{l}\text { High blood } \\
\text { pressure }\end{array}$ \\
\hline $\mathrm{K}^{+}$ & $1.3-109$ & $1.5-91$ & 12 & $\begin{array}{c}1,7,14,24,28,38 \\
45,51,58(13 \%)\end{array}$ & $\begin{array}{c}1,7,14,24,28,38,45,51 \\
58(13 \%)\end{array}$ & Bitter taste \\
\hline $\mathrm{HCO}_{3}^{-}$ & $220-657$ & $248-666$ & 600 & $\begin{array}{c}15,20,24,34,42,58 \\
(9 \%)\end{array}$ & $\begin{array}{c}15,20,24,34, \\
42,47,58(10 \%)\end{array}$ & - \\
\hline $\mathrm{Cl}^{-}$ & $54-494$ & $76-513$ & 600 & - & - & Salty taste \\
\hline $\mathrm{PO}_{4}^{3-}$ & $0.2-7.3$ & $0.2-14$ & & - & - & - \\
\hline $\mathrm{F}^{-}$ & $0.2-5$ & $0.2-6$ & 1.5 & $\begin{array}{c}7,16,17,19,20,23 \\
32,42,46,51 \\
(14 \%)\end{array}$ & $\begin{array}{c}7,15,16,17,19,20,21,23 \\
25,32,42,45,46,51,52 \\
(21 \%)\end{array}$ & $\begin{array}{l}\text { Mottling of tooth, } \\
\text { deformation of bones }\end{array}$ \\
\hline $\mathrm{NO}_{3}^{-}$ & $1.3-90$ & $2.2-106$ & 50 & $7,13,19,62,66(7 \%)$ & $7,13,19,62,66(7 \%)$ & Methaemoglobinaemia \\
\hline $\mathrm{SO}_{4}^{2-}$ & $2.2-302$ & $3.9-316$ & 600 & - & - & Laxative effect \\
\hline $\mathrm{TH}$ & $140-720$ & $144-776$ & 500 & $\begin{array}{c}26,29,30,34,46,47, \\
58,65(11 \%)\end{array}$ & $\begin{array}{c}15,26,29,30,34,46,47, \\
58,65(13 \%)\end{array}$ & Scale formation \\
\hline $\mathrm{TA}$ & $180-539$ & $203-546$ & - & - & - & Unpleasant \\
\hline $\mathrm{pH}$ & $6.9-7.9$ & $7-7.9$ & 9.2 & - & - & Taste \\
\hline TDS & $258-1120$ & $267-1281$ & 1,500 & - & - & $\begin{array}{l}\text { Gastrointestinal } \\
\text { irritation }\end{array}$ \\
\hline
\end{tabular}


with the lithologic framework. The term hydrochemical facies is used to describe the bodies of groundwater in an aquifer, that differ in their chemical composition. The facies are a function of the lithology, solution kinetics and flow patterns of the aquifer. Hydochemical facies can be classified on the basis of dominant ion using the piper's trilinear diagram. The concentrations of major ionic constituents of groundwater samples were plotted in the piper trilinear diagram [8] to determine the water type (Figure 2 and Figure 3). Piper's trilinear diagram method is used to classify the groundwater, based on basic geochemical characters of the constituent ionic concentrations. The diagram consists of two triangular fields and a central diamond shaped field. The diamond shaped field between the two triangles is used to represent the composition of water with respect to both cations and anions. In the two tri-angular fields, percentage epm values of major cations and anions are plotted separately

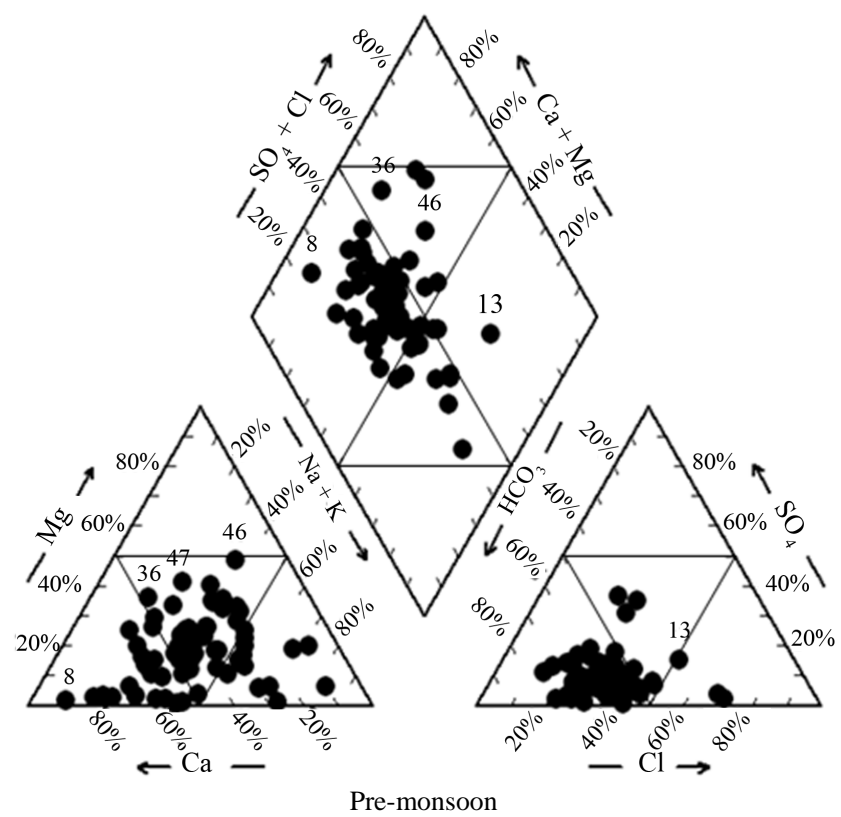

Figure 2. Piper diagram showing the relative cation and anion composition of groundwater samples.

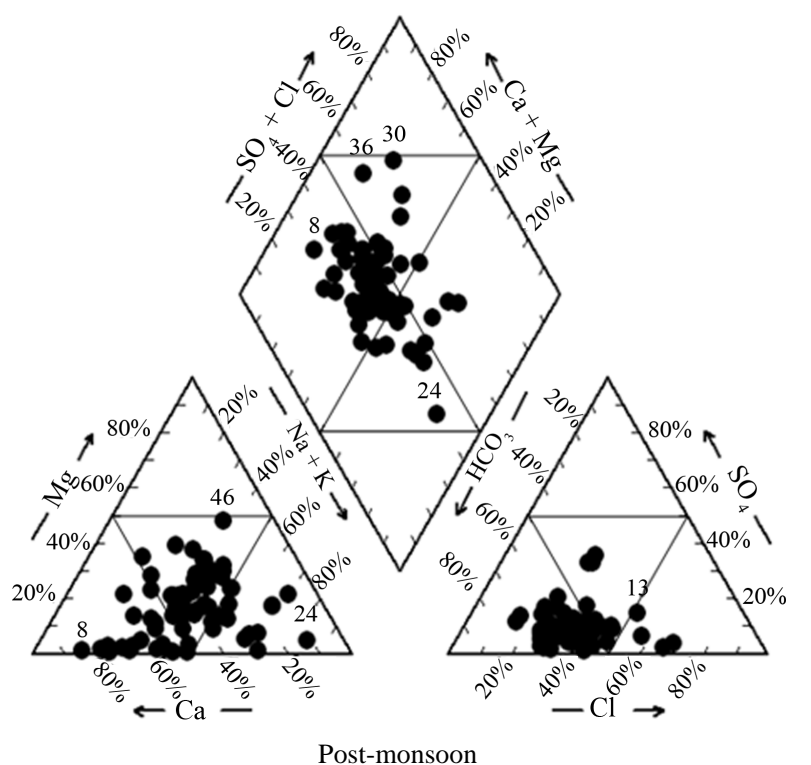

Figure 3. Piper diagram showing the relative cation and anion composition of groundwater samples. 
and then projected on to the central field for the representation of overall characteristic of water. The classification for cation and anion facies, in terms of major ion percentages and water type, is according to the domain in which they occur on the diagram segments [9]. From the cationic and anionic triangular files of piper diagram, it is observed that $52 \%, 27 \%$ and $21 \%$ of groundwater samples fall into the no dominant, Ca and Na fields in cation facies of pre-monsoon respectively, whereas $50 \%, 27 \%$ and $23 \%$ of groundwater samples fall into the no dominant, $\mathrm{Ca}$ and Na fields in cation facies of post-monsoon, respectively. Conversely $87 \%, 4 \%$ and $9 \%$ of groundwater samples fall into the $\mathrm{HCO}_{3}, \mathrm{Cl}$ and no dominant fields in anion facies of pre-monsoon, respectively, whereas $81 \%, 6 \%$ and $13 \%$ of groundwater samples fall into the $\mathrm{HCO}_{3}, \mathrm{Cl}$ and no dominant fields in anion facies of post-monsoon, respectively.

The plot of the chemical data on diamond shaped trilinear diagram (Figure 2 and Figure 3) reveals that majority of the groundwater samples fall in the field of 1, 3, 5 suggesting that alkaline earth exceeds alkalies, weak acids exceeds strong acids and the ions representing carbonate hardness (secondary alkalinity) exceeds 50\% respectively (Table 2) in both season. From the data plots, it is apparent that the total hydrochemistry is dominated by alkaline earths and weak acids. However, some of the groundwater samples having high sulfate and chloride concentration fall in 2 and 4 fields indicating alkalies exceeds alkaline earths and strong acids exceeds weak acids. Some samples also fall in the field 9 indicating mixed water having no one cation-anion pair exceeds 50\%. 2 samples fall in the field of 7 indicating that non-carbonate alkali (primary salinity) exceeds $50 \%$. The diagram indicates dominance of the major ions $\mathrm{Ca}, \mathrm{Na}$ and $\mathrm{HCO}_{3}$ while other ions, such as $\mathrm{Mg}, \mathrm{SO}_{4}$ and $\mathrm{Cl}$ are comparatively less represented.

\subsection{Groundwater Suitability for Drinking and Domestic Purposes}

The water used for drinking should be free from colour, turbidity and microorganism. To understand the groundwater suitability for drinking and public health use, hydrochemical parameters of the study area are compared (Table 1) with the guidelines prescribed by World Health Organization [10]. From the Table 1, it is evident that $3 \%$ and $4 \%$ samples in pre- and post-monsoon for calcium ion, $7 \%$ and $10 \%$ samples for sodium ion in pre- and post-monsoon, $13 \%$ samples for potassium ion in pre- and post-monsoon, $14 \%$ and $21 \%$ samples for fluoride ion in pre- and post-monsoon, $7 \%$ sample for nitrate ion in pre- and post-monsoon and $9 \%$ and $10 \%$ samples for bicarbonate ion in pre- and post-monsoon are exceeding the permissible limit set by WHO.

The $\mathrm{pH}$ values of groundwater samples range between 6.9 and 7.9 in pre-monsoon and 7 to 7.9 in post-monsoon season, which indicates that the groundwaters are slightly alkaline in nature. In general, groundwater $\mathrm{pH}$ is slightly alkaline due to the influx of $\mathrm{HCO}_{3}$ ions in the groundwater aquifer which is due to percolation of rain water through soil [11] [12]. Total dissolved solids (TDS) mainly consist of inorganic salts such as carbonates, bicarbonates, chlorides, sulfates, phosphates and nitrates of calcium, magnesium, sodium, potassium, iron etc and small amount of organic matter and dissolved gases. The concentration of (TDS) is ranging from 258 to $1120 \mathrm{mg} / \mathrm{l}$ in pre-monsoon and 267 to $1281 \mathrm{mg} / \mathrm{l}$ in post-monsoon (Table 1). To ascertain the suitability of ground-

Table 2. Distribution of groundwater samples (\%) in the subdivisions of Piper diagram (Piper 1953).

\begin{tabular}{|c|c|c|c|}
\hline \multirow{2}{*}{ Area } & \multirow{2}{*}{ Sub-division } & \multicolumn{2}{|c|}{ Sample fall (\%) } \\
\hline & & Pre & Post \\
\hline 1 & Alkaline earths exceed alkalies & $80 \%$ & $77 \%$ \\
\hline 2 & Alkalies exceed alkaline earths & $20 \%$ & $23 \%$ \\
\hline 3 & Weak acids exceed strong acids & $87 \%$ & $79 \%$ \\
\hline 4 & Strong acids exceed weak acids & $13 \%$ & $21 \%$ \\
\hline 5 & Carbonate hardness (secondary alkalinity) exceeds 50\% & $70 \%$ & $64 \%$ \\
\hline 6 & Non-carbonate hardness (secondary salinity) exceeds 50\% & $0 \%$ & $0 \%$ \\
\hline 7 & Non-carbonate alkali (primary salinity) exceeds 50\% & $3 \%$ & $6 \%$ \\
\hline 8 & Carbonate alkali (primary alkalinity) exceeds 50\% & $0 \%$ & $0 \%$ \\
\hline 9 & No one cation-anion pair exceeds $50 \%$ & $27 \%$ & $30 \%$ \\
\hline
\end{tabular}


water for any purposes, it is essential to classify the groundwater depending upon their hydro chemical properties based on their TDS values [13] [14] (Table 3). Based on total dissolved solids classification [13], 70\% in pre-monsoon and 59\% in post-monsoon are desirable for drinking purposes, $29 \%$ in pre- and $40 \%$ in post-monsoon are permissible for drinking and $1 \%$ in pre and post-monsoon are useful for agricultural purposes. According to Freeze and Cherry classification [14], 99\% sample in pre and post monsoon belongs to fresh water category and $1 \%$ sample is brackish water. The classification of groundwater based on total hardness (TH) shows that $69 \%$ in pre- and $82 \%$ in post-monsoon samples (Table 3 ) fall in the very hard water category. Groundwater exceeding the limit of $300 \mathrm{mg} / \mathrm{l}$ is considered to be very hard water [15]. Hard water leads to incidence of urolithiosis, anencephaly, parental mortality, some types of cancer [16] and cardio-vascular disorders [17]. Such waters can also develop scales in water heaters, distribution pipes and well pumps, boilers and cooking utensils, and require more soap for washing clothes [18]-[20]. 30\% and 17\% groundwater samples in all the samples fall in moderately-hard category in pre- and post-monsoon, respectively and rest $1 \%$ groundwater sample indicates that slightly hard water in both the seasons. Among the cationic (Ca, Mg, Na and $\mathrm{K}$ ) concentrations, sodium is the dominant ion (14 - $285 \mathrm{mg} / \mathrm{l}$ in pre and 25 - $298 \mathrm{mg} / \mathrm{l}$ in post) followed by calcium (30 - $260 \mathrm{mg} / \mathrm{l}$ in pre and $34-267 \mathrm{mg} / \mathrm{l}$ in post), magnesium (1.1 - $109 \mathrm{mg} / \mathrm{l}$ in pre and 1.1 - $110 \mathrm{mg} / \mathrm{l}$ in post) and potassium (1.3 - 109 $\mathrm{mg} / \mathrm{l}$ in pre and 1.5 - $91 \mathrm{mg} / \mathrm{l}$ in post) in both the seasons. In general weathering, dissolution and base-exchange

Table 3. Classification of groundwater based on different parameters for different purposes.

\begin{tabular}{|c|c|c|c|c|}
\hline \multirow{2}{*}{ Parameters } & \multirow{2}{*}{ Range } & \multirow{2}{*}{ Classification } & \multicolumn{2}{|c|}{$\%$ of sample } \\
\hline & & & Pre-monsoon & Post-monsoon \\
\hline \multirow{4}{*}{$\begin{array}{c}\text { TDS } \\
\text { (David and De } \\
\text { Wiest,1966) }\end{array}$} & $<500$ & Desirable for drinking & $70 \%$ & $59 \%$ \\
\hline & $500-1000$ & Permissible for drinking & $29 \%$ & $40 \%$ \\
\hline & $1000-3000$ & Useful for agriculture & $1.00 \%$ & $1.00 \%$ \\
\hline & $>3000$ & Unfit for drinking and irrigation & & \\
\hline \multirow{5}{*}{$\begin{array}{c}\text { TDS } \\
\text { (Freeze and Cherry, 1979) }\end{array}$} & $<1000$ & Fresh water & $99 \%$ & $99 \%$ \\
\hline & $1000-10,000$ & Brackish water & $1 \%$ & $1 \%$ \\
\hline & $10,000-100,000$ & Saline water & & \\
\hline & $>100,000$ & Brine water & & \\
\hline & $<75$ & Soft & & \\
\hline \multirow{3}{*}{$\begin{array}{c}\text { Hardness } \\
\text { (Sawyer and Mc. Cartly, } \\
\text { 1967) }\end{array}$} & $75-150$ & Slightly hard & $1 \%$ & $1 \%$ \\
\hline & $150-300$ & Moderately hard & $30 \%$ & $17 \%$ \\
\hline & $>300$ & Very hard & $69 \%$ & $82 \%$ \\
\hline \multirow{8}{*}{$\begin{array}{c}\text { Chloride } \\
\text { (Stuyfzand,1989) }\end{array}$} & $<0.141$ & Extremely fresh & & \\
\hline & $0.141-0.846$ & Very fresh & & \\
\hline & $0.846-4.231$ & Fresh & $64 \%$ & $53 \%$ \\
\hline & $4.231-8.462$ & Fresh brackish & $32 \%$ & $40 \%$ \\
\hline & $8.462-28.206$ & Brackish & $4 \%$ & $7 \%$ \\
\hline & $28.206-282.064$ & Brackish salt & & \\
\hline & $282.064-564.127$ & Salt & & \\
\hline & $>564.127$ & Hyperhaline & & \\
\hline \multirow{5}{*}{ WQI } & $<50$ & Excellent water & $0 \%$ & $0 \%$ \\
\hline & $50-100$ & Good water & $50 \%$ & $54 \%$ \\
\hline & $100-200$ & Poor water & $34 \%$ & $24 \%$ \\
\hline & $200-300$ & Very poor water & $9 \%$ & $12 \%$ \\
\hline & $>300$ & $\begin{array}{l}\text { Water unsuitable for } \\
\text { drinking purposes }\end{array}$ & $7 \%$ & $10 \%$ \\
\hline
\end{tabular}


processes control the levels of cationic concentrations in groundwater. High concentration of Na and Ca in the groundwater is attributed to cation exchange among minerals. Na was higher in both seasons indicating weathering from plagioclase bearing rocks. $\mathrm{K}$ was lesser in both the seasons indicating its lower geochemical mobility. Among the anionic $\left(\mathrm{HCO}_{3}, \mathrm{Cl}, \mathrm{PO}_{4}, \mathrm{~F}, \mathrm{NO}_{3}, \mathrm{SO}_{4}\right)$ concentrations bicarbonate is the dominant ion (220 - 657 $\mathrm{mg} / \mathrm{l}$ in pre and 248 - $666 \mathrm{mg} / \mathrm{l}$ in post), followed by chloride (54 - $494 \mathrm{mg} / \mathrm{l}$ in pre and 76 - $513 \mathrm{mg} / \mathrm{l} \mathrm{in} \mathrm{post}$ ), sulphate (2.2 - $302 \mathrm{mg} / \mathrm{l}$ in pre and 3.9 - $316 \mathrm{mg} / \mathrm{l}$ in post), nitrate (1.3 - $90 \mathrm{mg} / \mathrm{l}$ in pre and 2.2 - $106 \mathrm{mg} / \mathrm{lin}$ post) and fluoride (0.2 - $5 \mathrm{mg} / \mathrm{l}$ in pre and 0.2 - $6 \mathrm{mg} / \mathrm{l}$ in post) in both the seasons.

Chloride in all the samples is below the [10] limit in pre- and post-monsoon, respectively (Table 1). The chloride limits have been laid down primarily from taste view point. However, no adverse health effects on human being have been reported by the use of water having high chloride concentrations [21]. Excess concentration of $\mathrm{Cl}$ in drinking water gives a salty taste and has a laxative effect in people not accustomed to it. Based on $\mathrm{Cl}$ classification [22], none of the samples in both seasons are fall in extremely fresh and very fresh category. $64 \%$ sample in pre- and 53\% in post-monsoon are fall in fresh water while $32 \%$ and $40 \%$ samples indicates fresh brackish category. $4 \%$ and $7 \%$ samples indicate that the brackish water type may be due to dumping of solid waste and intense agricultural practice (Table 3).

Five and seven samples, out of 70 collected groundwater samples are exceeding the permissible limits ( $>200$ $\mathrm{mg} / \mathrm{l}$ ) of sodium content in the study area in pre-and post-monsoon season, respectively (Table 1). A sodiumrestricted diet is recommended to patients suffering from hypertension or congenial heart diseases and also from kidney problems. For such people, extra intake of Na through drinking water may prove critical [23]. Na has different role in human body. It is related with the function of nervous system, membrane system and excretory system. Excess sodium causes high pressure, nervous disorder, etc. Ten and fifteen samples, out of 70 groundwater samples are exceeding the permissible limits $(>1.5 \mathrm{mg} / \mathrm{l})$ of fluoride content in the study area in pre-and post-monsoon season, respectively (Table 1). Fluoride is an essential element for maintaining normal development of healthy teeth and bones. Deficiency of $\mathrm{F}$ in drinking water below $0.6 \mathrm{mg} / \mathrm{l}$ contributes to tooth caries. An excess of over $1.2 \mathrm{mg} / \mathrm{l}$ causes fluorosis [24].

Four and five samples, out of 70 groundwater samples are exceeding the permissible limits $(>50 \mathrm{mg} / \mathrm{l})$ of nitrate content in the study area in pre- and post-monsoon season, respectively (Table 1 ). Concentrations of $\mathrm{NO}_{3}$ are the result of different pollution processes involving municipal wastewaters, fertilizers (containing NPK) and the application of agricultural pesticides, among others. The highest $\mathrm{NO}_{3}$ Concentrations were observed in areas where large amounts of $\mathrm{N}$ fertilizers (commonly urea, nitrate or ammonium compounds) are used due to intensive agricultural practices. Excessive $\mathrm{NO}_{3}$ in drinking water can cause a number of health disorders, such as methemoglobinemia, gastric cancer, goitre, birth malformations and hypertension [25]. The high concentration of nitrate is due to the intensive urbanization and industrialization [9].

\subsection{Water Quality Index (WQI)}

Water quality index (WQI) is a simple and concise method useful for indicating impairment of water quality. WQI helps for the better management of water quality issues and improve the effectiveness of protective measures. It is an important parameter to classify water quality for suitability of drinking purposes [26]. The standards for drinking purposes as recommended by BIS 10,500 (2003) have been considered for the calculation of WQI (Table 4). WQI calculation has been done by assigning weights $\left(w_{i}\right)$ according to relative importance of each chemical parameter for drinking purposes (Table 4). The parameters like chloride, nitrate, total dissolved solids, fluoride, iron and sulfate has been assigned maximum weight 5 because of the major importance in water quality assessment [27]. Bicarbonate and phosphate is given the minimum weight of 1 as it plays an insignificant role in the water quality. Other parameters like calcium, magnesium, sodium, total hardness (TH), manganese, silicate and potassium were assigned weight between 1 and 5 depending on their importance in water quality determination. The relative weight $\left(W_{i}\right)$ is computed (Table 4$)$ from the following equation:

$$
W_{i}=\frac{w_{i}}{\sum_{i=1}^{n} w_{i}}
$$

where, $W_{i}$ is the relative weight, $w_{i}$ is the weight of each parameter and $n$ is the number of parameters.

A quality rating scale $\left(q_{i}\right)$ for each parameter is assigned by dividing its concentration in each water sample by 
Table 4. Relative weight of chemical parameters.

\begin{tabular}{cccc}
\hline Chemical parameters & BIS $(\mathrm{mg} / \mathrm{l})$ & Weight $\left(w_{i}\right)$ & Relative weight $\left(W_{i}\right)$ \\
\hline $\mathrm{TH}$ & 300 & 2 & 0.047 \\
$\mathrm{Ca}$ & 75 & 3 & 0.07 \\
$\mathrm{Mg}$ & 30 & 3 & 0.07 \\
Alkalinity & 200 & 1 & 0.023 \\
$\mathrm{Cl}$ & 250 & 5 & 0.116 \\
$\mathrm{TDS}$ & 500 & 5 & 0.116 \\
$\mathrm{~F}$ & 1 & 5 & 0.116 \\
$\mathrm{Mn}$ & 0.1 & 4 & 0.093 \\
$\mathrm{NO}$ & 45 & 5 & 0.116 \\
$\mathrm{Fe}$ & 0.3 & 5 & 0.116 \\
$\mathrm{SO}_{4}$ & 200 & 1 & 0.023 \\
$\mathrm{PO}_{4}$ & 0 & 4 & 0.093 \\
$\mathrm{Na}$ & 0 & 2 & 0.047 \\
$\mathrm{~K}$ & 0 & 2 & 0.047 \\
$\mathrm{Silicate}$ & 0 & 2 & 0.047 \\
& & $2 w_{i}=49$ & $\sum W_{i}=1.14$ \\
\hline
\end{tabular}

its respective standard according to the guidelines laid down in the [28] and the result is multiplied by 100:

$$
q_{i}=\left(C_{i} / S_{i}\right) \times 100
$$

where, $q_{i}$ is the quality rating, $C_{i}$ is the concentration of each chemical parameter in each water sample in milligrams per liter, $S_{i}$ is the Indian drinking water standard for each chemical parameter in milligrams per liter according to the guidelines of the [28]. For computing the WQI, the SI is first determined for each chemical parameter, which is then used to determine the WQI as per the following equation:

$$
\begin{aligned}
& \mathrm{SI}_{i}=W_{i} \times q_{i} \\
& \mathrm{WQI}=\sum \mathrm{SI}_{i}
\end{aligned}
$$

where $S I_{i}$ is the sub-index of $i$ th parameter, $q_{i}$ is the rating based on concentration of $i$ th parameter, $n$ is the number of parameters. The WQI range and type of water can be classified as excellent water $(<50)$; good water $(50$ 100); poor water (100 - 200); very poor water (200 - 300); water unsuitable for drinking purposes (>300) (Table 3). The calculated WQI values of the study area ranges from 51.7 to $405 \mathrm{mg} / \mathrm{l}$ in pre- and 53 to $484 \mathrm{mg} / \mathrm{l}$ in post-monsoon (Figure 4 and Figure 5).

Out of 70 groundwater sample, 50\% in pre- and 54\% in post-monsoon represents good water, $34 \%$ in pre- and $24 \%$ in post-monsoon indicate poor water, and $9 \%$ in pre- and $12 \%$ in post-monsoon shows very poor water and $7 \%$ in pre- and $10 \%$ in post-monsoon indicate water unsuitable for drinking purposes. This may be due to effective leaching of ions, overexploitation of groundwater, direct discharge of effluents, and agricultural impact. The high value of WQI at some locations has been found to be mainly from the higher values of iron, nitrate, total dissolved solids, hardness, fluorides, bicarbonate and manganese in the groundwater.

\subsection{Water Quality for Irrigation Purposes}

The concentration and composition of dissolved constituents in groundwater determine its quality for irrigation use. The suitability of groundwater for irrigation is liable on the effects of the mineral constituents in the water on both the plants and soil [29]. Higher salt content in irrigation water causes an increase in soil solution osmotic pressure [30]. Effect of salts on soil causing changes in soil structure, permeability and ae- 


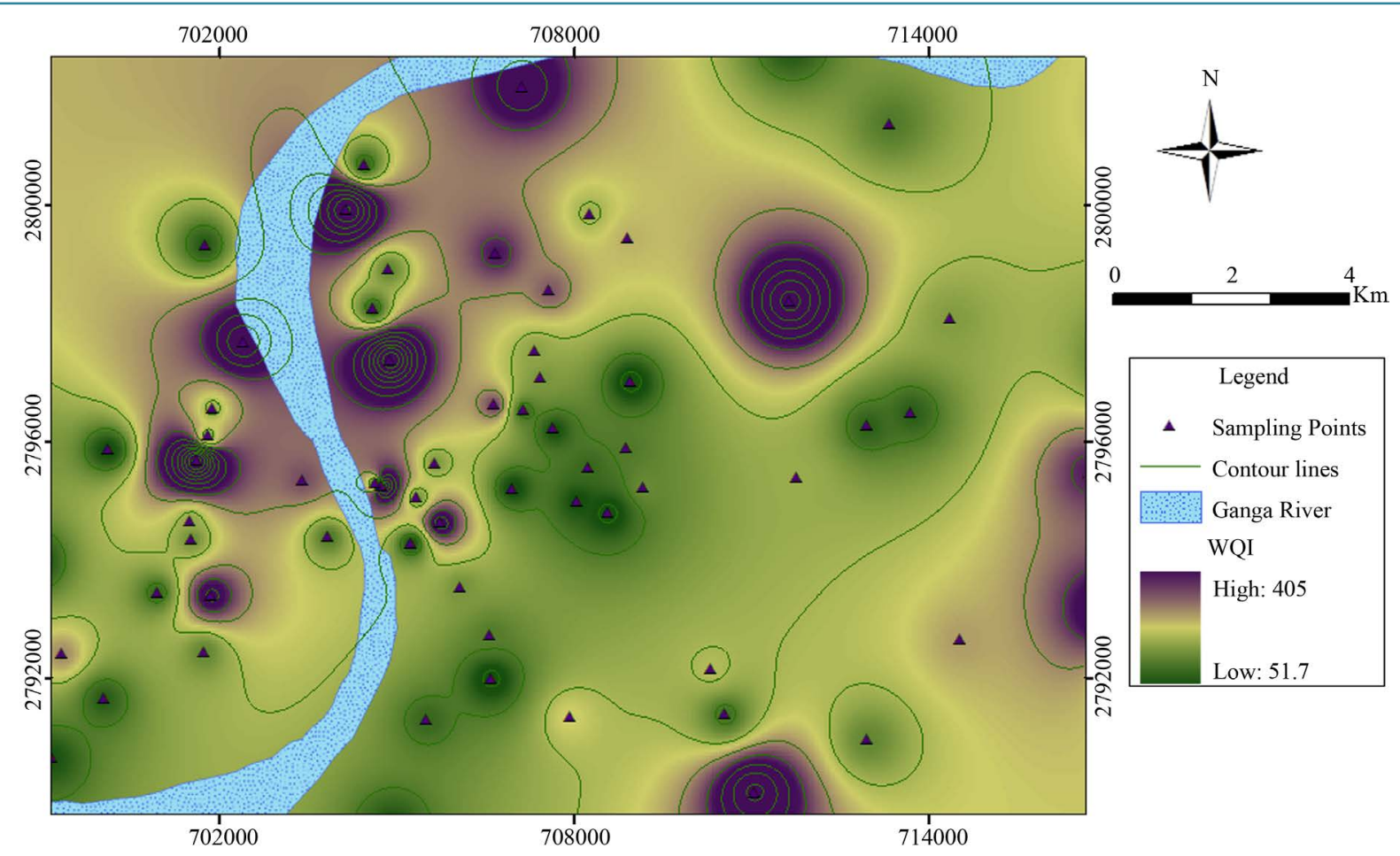

Figure 4. Spatial distribution of water quality index (mg/l) during pre-monsoon season.

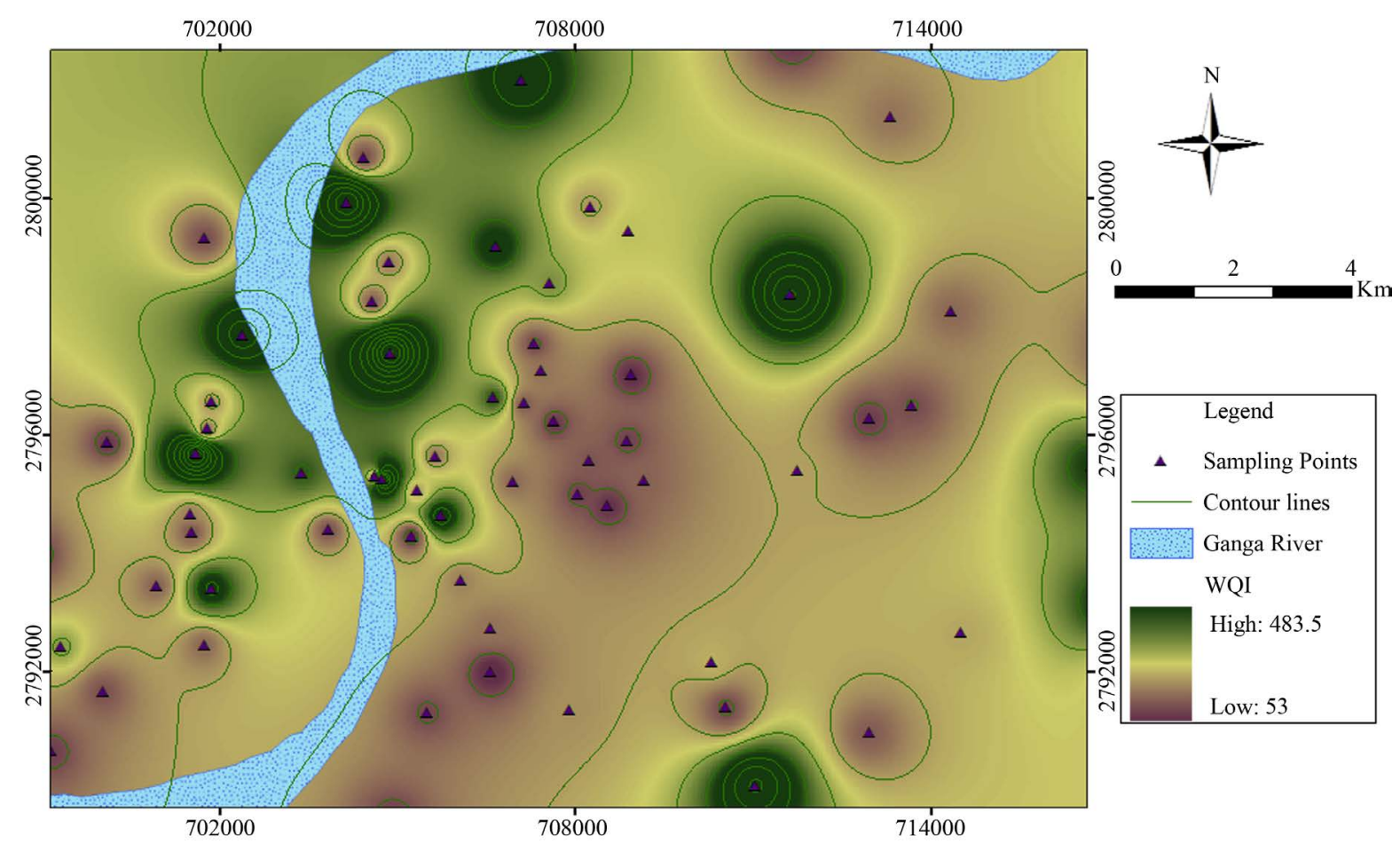

Figure 5. Spatial distribution of water quality index (mg/l) during post-monsoon season.

ration in directly affect plant growth. Since plant roots extract water osmosis, the water uptake of plants decreases. The osmotic pressure is proportional to the salt content or salinity hazard. The salts, besides affecting the growth of plants directly, also affect the soil structure, permeability and aeration, which indirectly affect the plant growth. An important factor allied to the relation of crop growth to water quality is drainage. 
If a soil is open and well drained, crops may be grown on it with the application of generous amounts of saline water; on the other hand, a poorly drained area combined with application of good quality water may fail to produce as satisfactory a crop [18].

The important chemical parameter for judging the degree of suitability of water for irrigation are sodium (\%Na), sodium adsorption ratio (SAR), residual sodium carbonate (RSC) and permeability index (PI).

\subsection{Sodium Percentage ( $\% \mathrm{Na}$ )}

Percent sodium (\% $\mathrm{Na}$ ) is also widely utilized for evaluating the suitability of water quality for irrigation [31]. Excess sodium concentration in groundwater produces the undesirable effects because Na reacts with soil to reduce its permeability and support little or no plant growth [9] [26]. The \% $\mathrm{Na}$ is computed with respect to relative proportions of cations present in water, where the concentrations of ions are expressed in meq/l, using the following formula:

$$
\mathrm{Na} \%=(\mathrm{Na}+\mathrm{K}) \times 100 /\{(\mathrm{Ca}+\mathrm{Mg}+\mathrm{Na}+\mathrm{K})\}(\mathrm{meq} / \mathrm{l})
$$

The calculated values of $\mathrm{Na} \%$ ranges 10.14 to 83.77 in pre- and 15.43 to 83.61 in post-monsoon. Generally, \% Na should not exceed $60 \%$ in irrigation waters. $8 \%$ sample in pre- and $11 \%$ sample in post-monsoon are higher than $60 \%$ of $\mathrm{Na} \%$ are unsafe for irrigation. The $\mathrm{Na} \%$ was higher may be dissolution of minerals from lithological composition, and the addition of chemical fertilizers by the irrigation waters [32].

\subsection{Sodium Absorption Ratio (SAR)}

The important chemical parameter for estimating the degree of suitability of water for irrigation as sodium content or alkali hazard for crops, which is expressed in sodium adsorption ratio (SAR). SAR is calculated from the ratio of sodium to calcium and magnesium. Calcium and magnesium ions are important since they are tending to counter the effect of sodium. Higher concentration of SAR leads to breakdown in the physical structure of the soil. Sodium is adsorbed and become attached to soil particles. The soil then become hard and compact when dry and impervious to water penetration. Sodium replacing adsorb calcium and magnesium is a hazard as it causes damage to the soil structure. The degree to which irrigation water tends to enter into cation exchange reaction in soil can be indicated by the SAR. The SAR recommended by the salinity laboratory of the US Department of Agriculture [31] is calculated using the formula:

$$
\mathrm{SAR}=\mathrm{Na}^{+} /\{(\mathrm{Ca}+\mathrm{Mg}) / 2\} 0.5(\mathrm{meq} / \mathrm{l})
$$

There is a close relationship between SAR values in irrigation water and the extent to which $\mathrm{Na}$ is absorbed by soils. If water used for irrigation is high in $\mathrm{Na}$ and low in $\mathrm{Ca}$, the ion-exchange complex may become saturated with $\mathrm{Na}$, which destroys soil structure, because of dispersion of clay particles. As a result, the soils tend to become deflocculated and relatively impermeable. Such soils can be very difficult to cultivate. The sodium hazard is expressed in terms of classification of irrigation water as low (S1: <10), medium (S2: 10 to 18), high (S3: 18 to 26) and very high (S4: >26). The SAR value in ground water sample range from 0.34 to 10.37 in pre-monsoon and 0.60 to 10.49 in post-monsoon indicating that all the groundwater samples are suitable for irrigation purposes (Table 5).

\subsection{Residual Sodium Carbonate (RSC)}

The excess sum of carbonate and bicarbonate in groundwater over the sum of calcium and magnesium also influences the suitability of groundwater for irrigation. When the excess carbonate concentration becomes too high, the carbonate combines with calcium and magnesium to form solid materials which settles out of the water. The relative abundance of sodium with respect to alkaline earths and the quantity of bicarbonates and carbonate in excess of alkaline earths also influence the suitability of water for irrigation. RSC is an important parameter to evaluate the suitability of irrigation water [9] [33], calculated using the formula.

$$
\mathrm{RSC}=\left[\left(\mathrm{HCO}_{3}+\mathrm{CO}_{3}\right)-(\mathrm{Ca}+\mathrm{Mg})\right](\mathrm{meq} / \mathrm{l})
$$

Generally, >2.5 meq/l of RSC is unsuitable for irrigation purposes. The RSC value in ground water sample range from -9.15 to 7.13 in pre-monsoon and -8.70 to 7.15 in post-monsoon was observed (Table 5). 
Table 5. Classification of groundwater for agricultural purposes.

\begin{tabular}{|c|c|c|c|c|c|c|}
\hline \multirow{2}{*}{ Parameter } & \multicolumn{2}{|c|}{ Sample range } & \multirow{2}{*}{ Range } & \multirow{2}{*}{ Classification } & \multicolumn{2}{|c|}{$\%$ of Sample } \\
\hline & Pre & Post & & & Pre & Post \\
\hline \multirow{5}{*}{$\begin{array}{l}\mathrm{Na} \% \\
(\mathrm{meq} / \mathrm{l})\end{array}$} & \multirow{5}{*}{$10-83.7$} & \multirow{5}{*}{$15.4-83.6$} & $0-20$ & Excellent & $6 \%$ & $4 \%$ \\
\hline & & & $20-40$ & Good & $54 \%$ & $47 \%$ \\
\hline & & & $40-60$ & Permissible & $32 \%$ & $37 \%$ \\
\hline & & & $60-80$ & Doubtful & $7 \%$ & $10 \%$ \\
\hline & & & $>80$ & Unsuitable & $1 \%$ & $1 \%$ \\
\hline \multirow{4}{*}{$\begin{array}{l}\text { SAR } \\
(\mathrm{meq} / \mathrm{l})\end{array}$} & \multirow{4}{*}{$0.34-10.37$} & \multirow{4}{*}{$0.60-10.49$} & $0-10$ & $\begin{array}{l}\text { Excellent (suitable for all types of crops } \\
\text { and soil except for those crops } \\
\text { sensitive to } \mathrm{Na} \text { ) }\end{array}$ & $100 \%$ & $100 \%$ \\
\hline & & & $10-18$ & $\begin{array}{l}\text { Good (suitable for coarse textured or } \\
\text { organic soil with permeability }\end{array}$ & - & - \\
\hline & & & $18-26$ & Fair (harmfully for almost all soils) & - & - \\
\hline & & & $>26$ & Poor (unsuitable for irrigation) & - & - \\
\hline \multirow{3}{*}{$\begin{array}{l}\mathrm{RSC} \\
(\mathrm{meq} / \mathrm{l})\end{array}$} & \multirow{3}{*}{$-9.15-7.13$} & \multirow{3}{*}{$-8.70-7.15$} & $<1.25$ & Good & $88 \%$ & $87 \%$ \\
\hline & & & $1.25-2.5$ & Medium & $6 \%$ & $7 \%$ \\
\hline & & & $>2.5$ & Bad & $6 \%$ & $6 \%$ \\
\hline \multirow{4}{*}{$\begin{array}{c}\mathrm{EC} \\
(\mu \mathrm{S} / \mathrm{cm})\end{array}$} & \multirow{4}{*}{$525-2240$} & \multirow{4}{*}{$535-2562$} & $<250$ & Low salinity hazard (good) & - & - \\
\hline & & & $250-750$ & Medium salinity hazard (moderate) & $36 \%$ & $33 \%$ \\
\hline & & & $750-2250$ & High salinity hazard (poor) & $64 \%$ & $66 \%$ \\
\hline & & & $>2250$ & Very high salinity hazard (very poor) & - & $1 \%$ \\
\hline \multirow{3}{*}{$\begin{array}{c}\text { PI } \\
\text { (meq/l) }\end{array}$} & \multirow{3}{*}{$35.8-102$} & \multirow{3}{*}{$36-101$} & Class I & Max. permeability & $11 \%$ & $14 \%$ \\
\hline & & & Class II & 75\% of Max. permeability & $89 \%$ & $86 \%$ \\
\hline & & & Class III & $25 \%$ of Max. permeability & - & - \\
\hline
\end{tabular}

The classifications of ground water for irrigation purpose according to the RSC values indicate that about $6 \%$ water sample in pre- and post-monsoon were beyond the permissible limit. $88 \%$ and $87 \%$ samples in preand post- monsoon have RSC value much less than $1.25 \mathrm{meq} / \mathrm{l}$ indicates that safe quality categories for irrigation while $6 \%$ and $7 \%$ in pre- and post-monsoon indicates that marginal quality for irrigation. Most of the sampling sites show the negative RSC value indicates that there is no complete precipitation of calcium and magnesium.

\subsection{Permeability Index (PI)}

Soil permeability is affected by long-term use of irrigation water with high salt content as influenced by $\mathrm{Na}^{+}$, $\mathrm{Ca}^{2+}, \mathrm{Mg}^{2+}$, and $\mathrm{HCO}_{3}$ contents of the soil. PI is defined by the following equation [34].

$$
\mathrm{PI}=\mathrm{Na}+\left(\mathrm{HCO}_{3}\right)^{2} / \mathrm{Ca}+\mathrm{Mg}+\mathrm{Na} * 100(\mathrm{meq} / \mathrm{l})
$$

The PI values $>75 \%$ comes under class I and indicates that the excellent quality of water for irrigation. The PI value between $25 \%$ - $75 \%$ comes under class II indicates that the good quality of water for irrigation and the PI value less than $25 \%$ comes under class III indicates that the unsuitable nature of water for irrigation. The calculated PI value ranges from 35.8 to $102 \mathrm{meq} / \mathrm{l}$ in pre-monsoon and 36 to 101 in post-monsoon respectively. According to the permeability index values, $11 \%$ and $14 \%$ of the groundwater in pre- and post-monsoon comes under class I (PI > 75\%) category while $89 \%$ and $86 \%$ in pre- and post-monsoon comes under class II (PI ranges from 25\% to 75\%) category. 


\subsection{US Salinity Laboratory's Diagram}

The US Salinity Laboratory's diagram [35] is widely used for rating the irrigation waters, where SAR is plotted against EC. The plots of chemical data of the groundwater samples in the US Salinity Laboratory's diagram are illustrated in Figure 6. The total concentrations of soluble salts in irrigation water can be classified into low (C1), medium (C2), high (C3) and very high (C4) salinity zones. The zones (C1 - C4) have the value of EC less than 250, $250-750,750-2250 \mu \mathrm{S} / \mathrm{cm}$ and more than $2250 \mu \mathrm{S} / \mathrm{cm}$, respectively. Higher EC in water creates a saline soil. The groundwater sample points, as shown as a cluster, fall in C2S1, C3S1, C3S2 and C4S1 zones. Figure 6 shows that the 37\% in pre- and 33\% in post-monsoon of the groundwater samples fall in the category of C2S1, indicating medium salinity and low alkali water, which can be used for irrigating most of the soils and crops with little danger of exchangeable sodium. However, $60 \%$ in pre- and $63 \%$ in post-monsoon of the water samples fall in C3S1 class, which shows a high salinity hazard and low alkali hazards [29]. However, two samples (3\% in pre and post-monsoon) fall in the C3S2 waters, indicating high salinity to a medium sodium type. This type of water may be used on coarse-textured or organic soils with good permeability [36]. 1\% sample in pre- and post-monsoon fall is C4S1 category indicating very high salinity and low alkalinity hazards. This water will be suitable for plants having good salt tolerance and it restricts the suitability for irrigation, especially in soils with restricted drainage. Moderate and bad water quality types are increased in post-monsoon due to enrichment of $\mathrm{Na}$ and EC concentrations. The good waters can be used for irrigation with little danger of harmful levels of exchangeable Na. The moderate waters can be used to irrigate salt-tolerant and semi-tolerant crops under favourable drainage conditions. The bad waters are generally undesirable for irrigation and should not be used on clayey soils of low permeability. Bad waters, however, can be used to irrigate plants of high salt tolerance, when grown on previously salty soils to protect against further decline of fertile lands.

\subsection{Wilcox's Diagram}

Wilcox's diagram [31] is adopted for the classification of groundwaters for irrigation, wherein the EC is plotted against \% Na. Data of pre- and post-monsoon groundwater samples of the area are plotted in the Wilcox's diagram (Figure 7). Out of the 70 groundwater samples, $37 \%$ in pre and $33 \%$ in post-monsoon of the groundwater

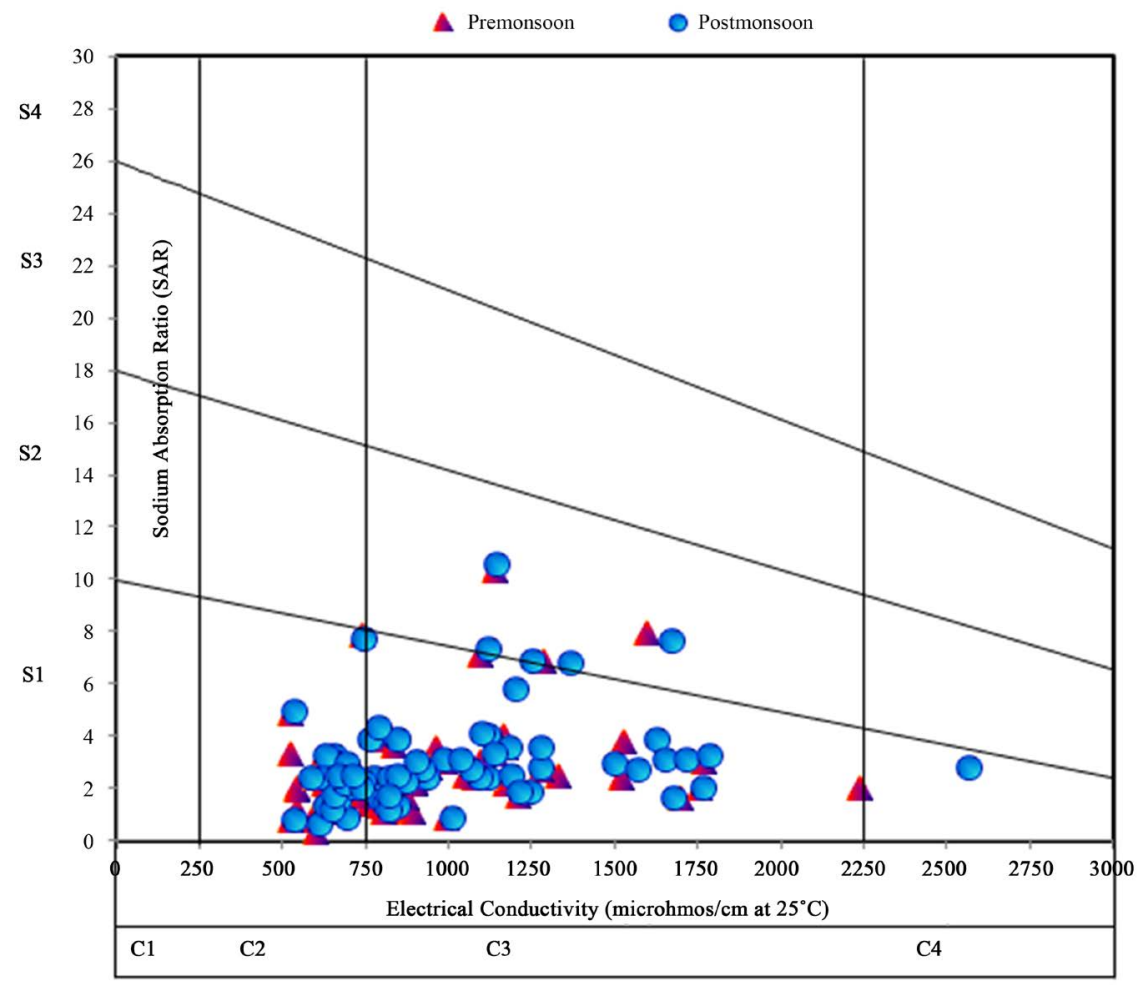

Figure 6. Classification of irrigation waters (after US Salinity Laboratory Staff 1954). 


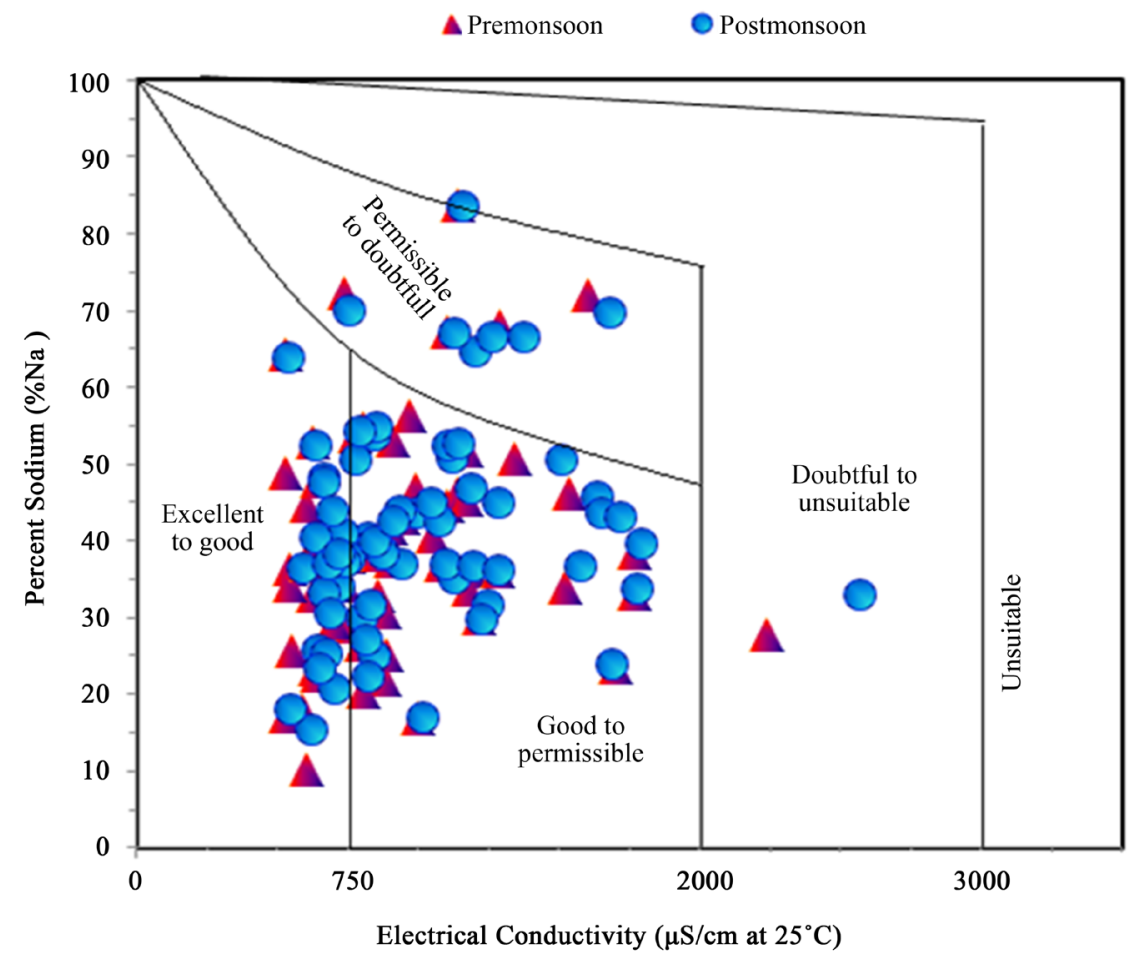

Figure 7. Classification of irrigation waters (after Wilcox 1948).

samples belong to excellent to good category followed by $52 \%$ in pre- and $56 \%$ in post-monsoon samples belonging to good to permissible category, $10 \%$ in pre- and post-monsoon belonging to permissible to doubtful, and $1 \%$ in pre- and post-monsoon sample belonging to doubtful to unsuitable category for irrigation use. The agricultural yields are generally low in lands irrigated with waters belonging to doubtful to unsuitable category. This is probably due to the presence of excess sodium salts, which cause osmotic effects on soil-plant system. When the concentration of sodium is high in irrigation water, sodium ions tend to be adsorbed by clay particles, displacing $\mathrm{Mg}$ and $\mathrm{Ca}$ ions by base-exchange process. This exchange process of $\mathrm{Na}$ in water for $\mathrm{Ca}$ and $\mathrm{Mg}$ in soil reduces permeability and eventually results in soil with poor internal drainage. Hence, air and water circulation is restricted during wet conditions, and such soils are usually hard when dry [37].

\section{Conclusion}

The study provides significant information on the development of ground water quality in parts of ChandauliVaranasi region. Ground water is immensely important for water supply in both urban and rural areas of developing nations. The major ion chemistry data revealed that the ground water in the study area is slightly hard to very hard and fresh to brackish in nature. According to the WHO (1997) classification of water based on TDS, all the samples are within the permissible limit. The sequence of the abundance of the major ions is in the following order of $\mathrm{Na}>\mathrm{Ca}>\mathrm{Mg}>\mathrm{K}$ for cations and $\mathrm{HCO}_{3}>\mathrm{Cl}>\mathrm{SO}_{4}>\mathrm{NO}_{3}>\mathrm{F}$ in anions. The alkali earth (Ca $+\mathrm{Mg}$ ) significantly exceeds alkalis $(\mathrm{Na}+\mathrm{K})$ and $\mathrm{HCO}_{3}$ and $\mathrm{Cl}$ exceeds the other anions in both the seasons. The WQI calculated exhibits poor quality in less percentage indicating the effective ion leaching, overexploitation and anthropogenic activities from discharge of effluents from agricultural and domestic uses in both the seasons. Based on the classification of irrigation water according to SAR and PI values, all the sample locations are suitable for irrigation purposes. Irrigation water quality based on $\% \mathrm{Na}$ indicates that $54 \%$ and $47 \%$ of the water samples belong to good category in pre- and post-monsoon, respectively. According to RSC values, $88 \%$ and $87 \%$ ground water samples are suitable for irrigation purposes in pre- and post-monsoon, respectively. Based on the Wilcox classification, $1 \%$ of the water samples belong to doubtful to unsuitable category for irrigation use due to the presence of excess sodium salts that cause deflocculating and reduce the permeability of soil. The analytical data plotted on the US Salinity diagram illustrate that $1 \%$ of the ground water samples fall in the field 
of C4S1, indicating high salinity, low sodium and 3\% samples fall in the field of C3S2 indicating high salinity and medium sodium hazard rendering it usable only on coarse-textured or organic soils with good permeability.

\section{References}

[1] Raju, N.J., Shukla, U.K. and Ram, P. (2011) Hydrogeochemistry for the Assessment of Groundwater Quality in Varanasi: A Fast-Urbanizing Center in Uttar Pradesh, India. Environmental Monitoring and Assessment, 173, $279-300$. http://dx.doi.org/10.1007/s10661-010-1387-6

[2] Raju, N.J. (2012) Evaluation of Hydrogeochemical Processes in the Pleistocene Aquifers of Middle Ganga Plain, Uttar Pradesh, India. Environmental Earth Sciences, 65, 1291-1308. http://dx.doi.org/10.1007/s12665-011-1377-1

[3] Shukla, U.K. and Raju, N.J. (2008) Migration of the Ganga River and Its Implication on Hydro-Geological Potential of Varanasi Area, UP, India. Journal of Earth System Science, 117, 489-498. http://dx.doi.org/10.1007/s12040-008-0048-4

[4] Raju, N.J. and Reddy, T.V.K. (2007) Environmental and Urbanization Affect on Groundwater Resources in a Pilgrim Town of Tirupati, Andhra Pradesh, South India. Applied Geochemistry, 9, 212-223.

[5] Sinha, T.K. (2003) Groundwater Conditions and Its Quality in Varanasi City. Indian Journal of Geomorphology, 8, 153-154.

[6] APHA (2005) Standard Methods for the Examination of Water and Wastewater. 25th Edition, American Public Health Association, Washington DC.

[7] Domenico, P.A. and Schwartz, F.W. (1990) Physical and Chemical Hydrogeology. John Wiley \& Sons, New York, 824.

[8] Piper, A.M. (1953) A Graphic Procedure in the Chemical Interpretation of Water Analysis. US Geological Survey Groundwater Note, 12.

[9] Raju, N.J., Ram, P. and Dey, S. (2009) Groundwater Quality in the Lower Varuna River Basin, Varanasi District, Uttar Pradesh, India. Journal of the Geological Society of India, 7, 178-192. http://dx.doi.org/10.1007/s12040-008-0048-4

[10] World Health Organization (1997) Guideline for Drinking Water Quality. 2nd Edition, Vol. 2, WHO, Geneva, Health criteria and Other Supporting Information, 940-949.

[11] Mor, S., Ravindra, K., De Visscher, A., Dahiya, R.P. and Chandra, A. (2006) Municipal Solid Waste Characterization and Its Assessment for Potential Methane Generation: A Case Study. Science of the Total Environment, 371, 1-10. http://dx.doi.org/10.1016/j.scitotenv.2006.04.014

[12] Alam, M., Rais, S. and Aslam, M. (2012) Hydrochemical Investigation and Quality Assessment of Ground Water in Rural Areas of Delhi, India. Environmental Earth Sciences, 66, 97-110. http://dx.doi.org/10.1007/s12665-011-1210-x

[13] Davis, S.N. and De Wiest, R.J.M. (1966) Hydrogeology, Vol. 463. Wiley, New York.

[14] Freeze, R.A. and Cherry, J.A. (1979) Groundwater. Prentice Hall, Engle Wood Cliffs, 604.

[15] Sawyer, G.N. and McCartly, D.L. (1967) Chemistry of Sanitary Engineers. 2nd Edition, McGraw Hill, New York, 518.

[16] Agrawal, V. and Jagetia, M. (1997) Hydrogeochemical Assessment of Groundwater Quality in Udaipur City, Rajasthan, India. Proceedings of National Conference on Dimensions of Environmental Stress in India, Baroda, 151-154.

[17] Durvey, V.S., Sharma, L.L., Saini, V.P. and Sharma, B.K. (1991) Handbook on the Methodology of Water Quality Assessment. Rajasthan Agriculture University, India.

[18] Todd, D.K. (1980) Ground Water Hydrology. Wiley, New York, 535.

[19] Hem, J.D. (1991) Study and Interpretation of the Chemical Characteristics of Natural Water. 3rd Edition, Scientific Publishers, Jodhpur, 2254.

[20] Karanth, K.R. (1997) Groundwater Assessment, Development and Management. Tata McGraw-Hill Publishing Company Limited, New Delhi.

[21] Jain, C.K., Bandyopadhyay, A. and Bhadra, A. (2010) Assessment of Ground Water Quality for Drinking Purpose, District Nainital, Uttarakhand, India. Environmental Monitoring and Assessment, 166, 663-676. http://dx.doi.org/10.1007/s10661-009-1031-5

[22] Stuyfzand, P.J. (1991) Non-Point Source of Trace Element in Potable Groundwater in Netherland. Proceedings of the 18th International Water Supply Congress and Exhibition (IWSA), Copenhagen, 25-31 May 1991, Water Supply 9.

[23] Holden, W.S. (1971) Water Treatment and Examination. John \& Churchill Publishers, London.

[24] ISI (1983) Indian Standard Specification for Drinking Water. IS: 10500. Indian Standard Institute, India.

[25] Majumdar, D. and Gupta, N. (2000) Nitrate Pollution of Groundwater and Associated Human Health Disorders. Indian Journal of Environmental Health, 42, 28-39.

[26] Vasanthavigar, M., Srinivasamoorthy, K., Vijayaragavan, K., Rajiv Ganthi, R., Chidambaram, S., Anandhan, P., Mani- 
vannan, R. and Vasudevan, S. (2010) Application of Water Quality Index for Groundwater Quality Assessment: Thirumanimuttar Sub-Basin, Tamilnadu, India. Environmental Monitoring and Assessment, 171, 595-609. http://dx.doi.org/10.1007/s10661-009-1302-1

[27] Srinivasamoorthy, K., Chidambaram, M., Prasanna, M.V., Vasanthavigar, M., Peter, J. and Anandhan, P. (2008) Identification of Major Sources Controlling Groundwater Chemistry from a Hard Rock Terrain-A Case Study from Mettur Taluk, Salem District, Tamilnadu, India. Journal of Earth System Sciences, 117, 49-58. http://dx.doi.org/10.1007/s12040-008-0012-3

[28] Bureau of Indian Standards (2003) Drinking Water-Specification IS: 10500. BIS, New Delhi.

[29] Richards, L.A. (1954) Diagnosis and Improvement of Saline Alkali Soils, Agriculture, 160, Handbook 60. US Department of Agriculture, Washington DC.

[30] Thorne, D.W. and Peterson, H.B. (1954) Irrigated Soils. Constable and Company Limited, London, 113. http://dx.doi.org/10.1097/00010694-195411000-00021

[31] Wilcox, L.V. (1948) Classification and Use of Irrigation Waters. U.S. Department of Agriculture, Washington DC, 962.

[32] Subba Rao, N., Prakasa Rao, J., John Devadas, D., Srinivasa Rao, K.V., Krishna, C. and Nagamalleswara Rao, B. (2002) Hydrogeochemistry and Groundwater Quality in a Developing Urban Environment of a Semi-Arid Region, Guntur, Andhra Pradesh, India. Journal of the Geological Society of India, 59, 159-166.

[33] Siddiqui, A., Naseem, S. and Jalil, T. (2005) Groundwater Quality Assessment in and around Kalu Khuhar, Super Highway, Sindh, Pakistan. Journal of Applied Sciences, 5, 1260-1265. http://dx.doi.org/10.3923/jas.2005.1260.1265

[34] Raghunath, H.M. (1987) Groundwater. Wiley Eastern Ltd., Delhi.

[35] US Salinity Laboratory Staff (1954) Diagnosis and Improvement of Saline and Alkali Soils. Agricultural Handbook No. 60, USDA, USA, 160.

[36] Karanth, K.R. (1989) Hydrogeology. McGraw-Hill, New Delhi.

[37] Collins, R. and Jenkins, A. (1996) The Impact of Agricultural Land Use on Stream Chemistry in the Middle Hills of the Himalayas, Nepal. Journal of Hydrology, 185, 71-86. http://dx.doi.org/10.1016/0022-1694(95)03008-5 